\title{
The Effect of Increased Transportation Costs on the Trade Flow of Fresh Peaches ${ }^{\dagger}$
}

\author{
Larry L. Bauer, Gary J. Wells, \\ David Tholstrup, and James Epperson**
}

\section{INTRODUCTION}

Increasing energy prices are bringing about disruptive changes in the economy of the United States and the world. The economies of the developed world are dependent on fossil fuels for the manufacture and transportation of essentially all commodities. One example of disruptions is the movement of fresh fruit, such as peaches. The production of fresh peaches is concentrated in the far West and the Southeastern United States from where they are shipped by truck or rail to the main consuming centers in the Northeast and Mid-west. Peaches are a perennial crop for which adjustments to changing economic situations require a number of years.

\section{OBJECTIVE}

The objective of this analysis is to measure the short-run effects of increased transportation costs on the producers and consumers of fresh peaches in the United States. This analysis will be short-run in that a perfectly inelastic supply is assumed.

\section{PROCEDURE}

The methodology used in this study is based on interregional competition theory which assumes the existence of one or more producing regions spatially separated from one or more consuming regions. It is further assumed that transporting the commodity from producer to consumer introduces transfer costs. Interregional competition theory explores the interaction of supply, demand, and transfer costs. The result is an estimate of the price and quantity of the commodity supplied and/or demanded in each region or market. It is expected that prices will vary from region to region because of the interaction of

†Technical Contribution No. 1819. South Carolina Agriculture Experiment Station.

** Professor, Assistant Professor, and former Graduate Assistant, Department of Agricultural Economics, Clemson University, and Assistant Professor, Department of Agricultural Economics, University of Georgia. 
the transfer cost with the regional supply and demand. If the difference in price between two markets is larger than the transfer cost and no other barriers to trade exist, both markets will benefit from trade. This situation is applicable to the peach industry because the price that prevails in many rural producing areas is far below the price of peaches in large metropolitan areas. Several techniques have been used in previous studies to obtain equilibrium solutions consistent with interregional competition theory. In this analysis a reactive programming algorithm developed by Tramel and Seale is used (2). The three elements of a reactive programming problem are: (1) transfer costs, (2) a demand function for each consumption area, and (3) a supply function or point supply for each production area. Transfer costs between each origin and destination were estimated with a least squares function in which the transfer cost was a function of the distance between the two points.

Reactive programming requires that the demand functions be of the form:

$$
\mathrm{P}=\mathrm{a}+\mathrm{bQ}
$$

where $\mathrm{P}$ is price, and $\mathrm{Q}$ is quantity. Any other independent variables used in estimation must be collapsed into the intercept or slope coefficients. For the current analysis the wholesale price of fresh peaches in each major terminal market was hypothesized to be dependent on: (1) the quantity of fresh peaches received in that terminal market, (2) the population of the Standard Metropolitan Statistical Area (SMSA) in which the terminal market is located, (3) the per capita personal income of the SMSA, and (4) the year. The terminal market demands were estimated by combining cross section and time series data, i.e. one demand function was estimated and differences between markets accounted for by dummy variables. As mentioned, this analysis is short-run in nature, so perfectly inelastic supply functions or fixed supplies are used.

The analysis covers the middle two weeks in July, a time period when the primary areas of supply are at a full level of production.

\section{DATA}

The least squares equation used to determine transfer costs was estimated with truck rates for peaches originating in North Carolina, South Carolina, Florida and Georgia. These data are unpublished and were obtained from a truck broker during the spring of 1979. Mileage data were obtained from a road map atlas.

The quantity data for the dependent variable in the demand relationship were obtained from unpublished information provided by Market News Service, USDA. The price data are from the same source and both cover the period 1972-76. Population and income data came from Department of Commerce publications (Stat. Abstract of U.S., Survey of Current Business).

The supply data are from Market News Service. The fixed annual supply for each area is based on an average of the period 1973-75. The supplies are 


\section{TABLE 1}

Reactive programming results for peaches, five producing regions, four consuming areas, given 1979 transfer costs and increases of 50 percent and 100 percent

\begin{tabular}{|c|c|c|c|c|c|}
\hline \multirow[b]{2}{*}{$\begin{array}{l}\text { Production } \\
\text { Area }\end{array}$} & & \multicolumn{4}{|c|}{ Consumption Areas } \\
\hline & & $\begin{array}{l}\text { Northeast } \\
(000 \mathrm{lb})\end{array}$ & $\begin{array}{l}\text { TX, OK, LA } \\
\text { (000 lb) }\end{array}$ & $\begin{array}{l}\text { Mid-west } \\
(000 \mathrm{lb})\end{array}$ & $\begin{array}{l}\text { West } \\
(000 \mathrm{lb})\end{array}$ \\
\hline \multirow[t]{3}{*}{ CA-WA } & Bench mark &.-- & $2,412.0$ & $2,533.5$ & $12,314.0$ \\
\hline & $50 \%$ increase & $\ldots$ & $1,517.5$ & $1,725.8$ & $14,016.3$ \\
\hline & $100 \%$ increase & $-\cdots$ & $1,068.8$ & 853.8 & $15,337.1$ \\
\hline \multirow{3}{*}{ NC-SC-GA } & Bench mark & $16,253.3$ & $\cdots$ & $11,258.6$ & $\cdots$ \\
\hline & $50 \%$ increase & $15,829.5$ & -.. & $11,682.6$ & -.. \\
\hline & $100 \%$ increase & $15,085.8$ & 146.3 & $12,280.0$ & $\ldots$ \\
\hline Other Sun & Bench mark & 636.0 & $1,885.3$ & --- & $\ldots$ \\
\hline \multirow[t]{2}{*}{ Belt } & $50 \%$ increase & $\ldots$ & $2,521.3$ & -.- & -.. \\
\hline & $100 \%$ increase & $\cdots$ & $2,521.3$ & $\cdots$ & -.. \\
\hline \multirow[t]{3}{*}{ NJ } & Bench mark & $1,862.0$ &.- & -- & 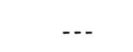 \\
\hline & $50 \%$ increase & $1,862.0$ & ... & -.. & $\ldots$ \\
\hline & $100 \%$ increase & $1,862.0$ & $\cdots$ & -.- & -.- \\
\hline \multirow[t]{3}{*}{ Other } & Bench mark & 452.2 & $\cdots$ & $1,394.6$ & -.- \\
\hline & $50 \%$ increase & 452.2 & $\ldots$ & $1,394.6$ & $\ldots$ \\
\hline & $100 \%$ increase & 452.2 & $\cdots$ & $1,394.6$ & $--\cdot$ \\
\hline \multirow[t]{3}{*}{ Total } & Bench mark & $19,203.5$ & $4,297.3$ & $15,186.7$ & $12,314.0$ \\
\hline & $50 \%$ increase & $18,143.7$ & $4,038.8$ & $14,803.0$ & $14,016.3$ \\
\hline & $100 \%$ increase & $17,400.0$ & $3,735.6$ & $14,534.4$ & $15,331.7$ \\
\hline
\end{tabular}

reported by state whereas demand information is reported by terminal market. Therefore, only state shipments to terminal markets are considered. For more detail on the supplies as well as the demands and transfer costs used in the reactive programming see (1).

\section{RESULTS}

Reactive programming tends to limit, relative to the actual situation, the number of markets that receive shipments from each origin. In this study the initial results tended to limit flows to markets that received shipments of less than 30,000 pounds. To overcome this problem, actual shipments of less than that amount were allocated by hand and subtracted from the available supply of the respective regions. Demand equations were adjusted to reflect these changes. 
The model did not allocate supplies to six terminal markets that actually received supplies in amounts larger than 30,000 pounds. These six centers were Atlanta, Birmingham, Columbia, Miami, Memphis, and Nashville. ${ }^{1}$ The demand and transfer cost equations constructed for these markets obviously did not take into account why these markets received shipments larger than 30,000 pounds. Therefore, the shipments to these six centers were allocated by hand and subtracted from the total available supply of the appropriate origin.

With these changes incorporated into the model, the predicted trade flows were more consistent with actual shipments. However, not all of the trade flows that actually occurred were predicted. The model incorporating the above changes predicted approximately 80 percent of the actual flows.

Table 1 presents the reactive programming results for five aggregated producing areas and four aggregated consuming centers. ${ }^{2}$ Results are presented for a bench mark run with 1979 transfer costs, and for runs where transfer costs were increased by 50 percent and 100 percent.

Theory would lead us to expect that as transfer costs increase, the California-Washington production area would ship more of its production to local markets in the West and less to eastern markets. The results indicate that with the 100 percent increase in transfer costs, the reduction in shipments to the Texas-Oklahoma-Louisiana area would amount to almost 56 percent while the reduction of shipments to the Mid-west amount to 66 percent. The increase in shipments to the Western consuming area would be almost 25 percent.

The change in shipping patterns from the other primary production area, Georgia and the Carolinas, would not be as substantial as for the Western producing region. With the 100 percent increase in transfer costs, the Southeastern production region reduces shipments to the Northeast by 7.2 percent, increases shipments to the Mid-west area by 9.1 percent, and begins shipping a relatively small quantity to the Texas-Oklahoma-Louisiana area.

The remaining states in the Southeast would also reduce shipments to the Northeast and increase those to the Texas-Oklahoma-Louisiana area.

The total result is a general shift of shipments from east to west. With a 100 percent increase in transfer costs, total shipments would be reduced by 9.4 percent to the Northeast, reduced by 13.1 percent to the Texas-OklahomaLouisiana area and reduced by 4.3 percent to the Mid-west. Conversely the shipments to the West would increase by 24.5 percent with the doubling in transfer costs.

The California-Washington production area would increase shipments to the local western markets at the expense of shipments to the Mid-west and the Texas-Oklahoma-Louisiana area. The Southeast would move into these two consuming areas to make up part of the reduction and reduce shipments to the Northeast.

The question arises as to the impact of reduced production on the flow pattern described thus far. This is the long run effect. Table 2 illustrates a situation where transfer costs have been increased by $100 \%$ and production reduced by 10 percent and compares these results to the base production level 


\section{TABLE 2}

Reactive programming results for peaches, five producing regions, four consuming areas, given a 100 percent increase over 1979 transfer costs and (I) average production for mid-July 1973 thru 1975 and (II) a 10 percent decline in production

\begin{tabular}{|c|c|c|c|c|c|}
\hline \multirow[b]{2}{*}{$\begin{array}{l}\text { Production } \\
\text { Area }\end{array}$} & & \multicolumn{4}{|c|}{ Consumption Areas } \\
\hline & & $\begin{array}{l}\text { Northeast } \\
\text { (percent) }\end{array}$ & $\begin{array}{c}\text { TX, OK, LA } \\
\text { (percent) }\end{array}$ & $\begin{array}{l}\text { Mid-west } \\
\text { (percent) }\end{array}$ & $\begin{array}{c}\text { West } \\
\text { (percent) }\end{array}$ \\
\hline \multirow[t]{2}{*}{ CA-WA } & I & $\cdots$ & 6.2 & 4.9 & 88.9 \\
\hline & II & -- & 6.0 & 3.4 & 90.6 \\
\hline \multirow[t]{2}{*}{ NC-SC-GA } & I & 54.8 & .5 & 44.6 & $--\cdot$ \\
\hline & II & 53.7 & .8 & 45.5 & $\cdots$ \\
\hline Other Sun & I & -- & 100.0 & $\cdots$ & $\cdots$ \\
\hline Belt & II & $--\cdot$ & 100.0 & $-\cdot-$ & $\cdots$ \\
\hline \multirow[t]{2}{*}{ NJ } & I & 100.0 & -.- &.-- & $-\cdots$ \\
\hline & II & 100.0 & $\cdots$ & $--\cdot$ & $--\cdot$ \\
\hline \multirow[t]{2}{*}{ Other } & I & 24.5 &.-- & 75.5 & -.. \\
\hline & II & 24.5 & $-\cdot$ & 75.5 & $\cdots$ \\
\hline
\end{tabular}

as shown in Table 1. As readily seen, flow patterns would not be substantially altered given reduced production. From this it can be concluded that the short run analysis contained in this paper is representative of the situation that exists in the peach industry.

\section{PRODUCER EFFECTS}

Given the short-run situation analyzed in this study, the inelastic supply would not enable any of the increased transfer costs to be directly passed on to the consumer. The immediate reaction of producers to attempt to reduce the increased transfer costs would be to reallocate peach flows to markets closer to their respective production area. However, even with these changes in allocation, there will be a reduction in producer revenue. Table 3 shows total producer revenue given 1979 transfer costs and increases of 50 percent and 100 percent.

Total revenue to producers would decrease by 8.9 percent when transfer costs are increased by 50 percent and by 17.8 percent when costs are increased by 100 percent. The largest percentage decrease in revenue occurs for the California-Washington production area. With a 50 percent increase in costs, their revenue would decrease by 11.5 percent and by 22.1 percent when transfer costs increase by 100 percent. The revenue decrease for the Georgia- 
TABLE 3

Reactive programming estimates of producer revenue for five producing regions, given 1979 transfer costs and increases of 50\% and 100\%

\begin{tabular}{|c|c|c|c|}
\hline \multirow[b]{2}{*}{$\begin{array}{l}\text { Production } \\
\text { Area }\end{array}$} & \multicolumn{3}{|c|}{ Producer Revenue } \\
\hline & $\begin{array}{c}1979 \text { Transfer } \\
\text { Costs }\end{array}$ & $\begin{array}{l}50 \% \text { Increase } \\
\text { in Transfer Costs }\end{array}$ & $\begin{array}{l}100 \% \text { Increase } \\
\text { in Transfer Costs }\end{array}$ \\
\hline $\begin{array}{l}\text { California- } \\
\text { Washington }\end{array}$ & $\$ 3,071,173$ & $\$ 2,719,294$ & $\$ 2,391,221$ \\
\hline NC, SC, Georgia & $5,314,343$ & $4,871,532$ & $4,413,572$ \\
\hline Other Sun Belt & 489,739 & 457,197 & 424,877 \\
\hline $\mathrm{NJ}$ & 388,754 & 373,330 & 356,875 \\
\hline Other & 376,057 & 356,613 & 337,634 \\
\hline Total & $\overline{\$ 9,640,066}$ & $\overline{\$ 8,777,966}$ & $\overline{\$ 7,924,179}$ \\
\hline
\end{tabular}

Carolinas production area would amount to 8.3 percent and 16.9 percent respectively for the 50 percent and 100 percent increases in transfer costs.

The loss in revenue indicated by this particular reactive programming model amounts to almost two million dollars. It is emphasized again that small shipments and some other situations were handled by hand. However, the direction and relative magnitude of the changes estimated here should be representative of occurrences in the U.S. economy.

\section{CONSUMER EFFECTS}

As the estimates in Table 1 indicate, consumers in the West would receive a substantially larger quantity of fresh peaches while those in the other three consuming areas receive smaller quantities. As mentioned, the perfectly inelastic supply relationship dictates that the producers will pay the total amount of the increases in transfer costs. However, the consumers in the three regions

\section{TABLE 4}

Reactive programming estimates of average wholesale prices in four consuming areas given 1979 transfer costs and increase of 50\% and 100\%

\begin{tabular}{|c|c|c|c|}
\hline \multirow[b]{2}{*}{$\begin{array}{l}\text { Consuming } \\
\text { Area }\end{array}$} & \multicolumn{3}{|c|}{ Wholesale Price of Fresh Peaches $(\$ / 1000 \mathrm{lb}$ ) } \\
\hline & $\begin{array}{l}1979 \text { Transfer } \\
\text { Cost }\end{array}$ & $\begin{array}{l}50 \% \text { Increase } \\
\text { in Transfer Cost }\end{array}$ & $\begin{array}{l}100 \% \text { Increase } \\
\text { in Transfer Cost }\end{array}$ \\
\hline Northeast & $\$ 229.50$ & $\$ 231.52$ & $\$ 232.94$ \\
\hline $\begin{array}{l}\text { Texas-Oklahoma- } \\
\text { Louisiana }\end{array}$ & 225.81 & 229.02 & 232.44 \\
\hline Mid-west & 226.33 & 226.92 & 226.86 \\
\hline West & 207.89 & 201.11 & 189.20 \\
\hline
\end{tabular}


that receive smaller quantities will incur a cost in that they receive a smaller quantity of peaches at a higher price. The estimated wholesale prices for the three assumed levels of transfer costs are given in Table 4.

The price increases are not of great magnitude. The 100 percent increase in transfer costs would bring about a 1.5 percent increase in prices in the Northeast consuming area and a 2.9 percent increase in the Texas-Oklahoma-Louisiana consuming area. The price in the Mid-west would increase by only about .5 percent as the result of the doubling of transfer costs. The estimated change of greatest magnitude is in the Western consuming area where the increase in quantity as the result of the doubling of transfer costs would bring about a nine percent decrease in prices.

\section{CONCLUSION}

Reactive programming was used to estimate a spatial equilibrium model for fresh peaches. The analysis was adjusted by deleting smaller shipments so that the model was reasonably accurate in estimating the remaining allocations.

The effect of increased transfer costs on the allocations of fresh peaches was then estimated by increasing 1979 transfer costs by 50 and 100 percent. The results indicated allocations to the West would increase substantially at the expense of the other three aggregated consuming areas in the nation, the biggest relative reduction being in the Texas-Oklahoma-Louisiana consuming area. Producer revenue would decrease for all areas, and consumer prices would increase slightly in those areas that received smaller quantities.

The results are consistent with economic theory and give some indication of the magnitude of the effects that expected transportation increases have on the spatial allocations of peaches.

\section{FOOTNOTES}

1. Discussion with Dr. G. Ansel King of Clemson University indicated that Atlanta, Birmingham and Columbia are not exclusively terminal markets in that a large volume of transshipments to other terminal markets occurs. King also indicated that Miami, Memphis and Nashville have special market characteristics that do not lend them to the spatial equilibrium analysis reported here.

2. "Other Sun Belt" producing states are Alabama, Arkansas, Florida, Louisiana, and Texas. "Other" producing states are Illinois, Kentucky, Maryland, Missouri, Ohio, Pennsylvania, Virginia and West Virginia. "North- east" terminal markets include Albany, Boston, Baltimore, Buffalo, New York City, Philadelphia, Providence and Washington, D.C.

"Texas, Oklahoma and Louisiana" terminal markets include New Orleans, Dallas, Ft. Worth, Oklahoma City, San Antonio and Houston. "Mid-west" terminal markets include Kansas City, Minneapolis-St. Paul, Chicago, Cincinnati, Detroit, Indianapolis, Louisville, Milwaukee, St. Louis, Cleveland, and Pittshurgh. "West" terminal markets include Denver, Los Angeles, Portland, Salt Lake City, San Francisco and Seattle.

\section{REFERENCES}

1. Tholstrup, David B. 1980. An Analysis of the Effect of Increased Transfer Cost and Reduced Production on the South Carolina Fresh Market Peach Industry: unpublished M.S. Thesis. Clemson University, Clemson. S.C

2. Tramel, Thomas E. and A. D. Seale, Jr. 1959 "Reactive Programming of Supply and De. mand Relations-Applications (1) Fresh
Vegetables," Journal of Farm Economics. 41:1012-1022.

3. U.S. Dept. of Commerce. 1978. Survey of Current Business. BEA. Washington, D.C.

4. U.S. Dept. of Commerce. 1972-75. Statistical Abstract of the United Siates: National Data Beok and (juide to Senteres. Burcau of the Census. Washington, D.C. 